\title{
IDEOLOGI KEMANUSIAAN DALAM PENDIDIKAN AGAMA ISLAM
}

\author{
Mukhamad Saekan \\ STAIN Kudus, Jawa Tengah, Indonesia \\ saekan@stainkudus.ac.id
}

\begin{abstract}
THE IDEOLOGY OF HUMANITY IN ISLAMIC EDUCATION.Undang Undang Sistem Pendidikan Nasional (UUSPN) Number 20 of 2003 explains that one of the main goals of education is that learners have spiritual and religious strength and noble character. It shows how important the position of Islamic education in the context of national education. In addition, the formulation of education contains clearly about humanity aspects that are implemented into the reality of social life so that the system of social life order created a sense of mutual respect, peace, harmony without any conflict among others. Therefore, the ideology of humanity is absolutely necessary to be implemented by the teachers (Guru PAI). This study will discuss at least three things: the understanding of Islamic Education, the understanding of humanity ideology and how to implement the ideology of humanity in Islamic education. In its implementation, the ideology of humanity can be done normatively and technically. Normatively can be done by having a proper point of view to the students in all aspects of education, technically can be done by applying some learning approaches such as active learning, cooperative learning, and fun learning.
\end{abstract}

Keywords: Ideology, Humanity, Islamic Education 


\begin{abstract}
Abstrak
Dalam undang-undang sistem pendidikan nasional (UUSPN) Nomor 20 tahun 2003 menjelaskan bahwa salah satu tujuan utama pendidikan adalah peserta didik memiliki kekuatan spiritual keagamaan dan akhlak mulia. Hal ini menunjukkan betapa pentingnya posisi pendidikan Agama Islam dalam konteks pendidikan nasional. Selain itu, rumusan tentang pendidikan memuat secara jelas tentang aspek aspek kemanusiaan yang terimplementasi kedalam realitas kehidupan sosial sehingga sistem tatanan kehidupan sosial tercipta rasa saling menghargai dan menghormati, damai, rukun tanpa ada konflik diantara sesama. Oleh sebab itu ideologi kemanusiaan mutlak perlu dilaksanakan oleh para tenaga pendidik (Guru PAI). Kajian ini setidaknya akan membahas tiga hal yaitu pengertian Pendidikan Agama Islam, pengertian ideologi kemanusiaan dan bagaimana mengimplementasikan ideologi kemanusiaan dalam pendidikan Agama Islam. Dalam Implementasinya ideologi kemanusiaan dapat dilakukan secara normatif dan secara teknis. Secara normatif dilakukan dengan cara memiliki cara pandang yang tepat terhadap peserta didik dalam segala aspek pendidikan, secara teknis dilakukan dengan cara melakukan beberapa pendekatan belajar seperti belajar aktif, kooperatif learning, dan pembelajaran yang menyenangkan.
\end{abstract}

Kata Kunci: Ideologi, Kemanusiaan, Pendidikan Agama Islam

\title{
A. Pendahuluan
}

Manusia dan pendidikan memiliki hubungan kausalitas sangat erat. Didalam proses kehidupan manusia tidak akan bisa lepas dari pendidikan, artinya manusia selama hidupnya harus menjalani proses pendidikan baik yang bersifat formal maupun non formal atau informal.

Pendidikan memiliki peran membentuk atau merubah tabiat manusia dari tidak tahu menjadi tahu, dari belum paham menjadi lebih paham, dari tidak memiliki sopan santun menjadi memiliki 
sopan santun, dari tidak memiliki keterampilan menjadi memiliki keterampilan. Hal ini dapat dilihat dari rumusan tentang pendidikan bahwa pendidikan adalah usaha sadar dan terencana untuk mewujudkan suasana belajar dan proses pembelajaran agar peserta didik secara aktif mengembangkan potensi dirinya untuk memiliki kekuatan spiritual keagamaan, pengendalian diri, kepribadian, kecerdasan, ahlak mulia, serta keterampilan yang diperlukan dirinya, masyarakat, bangsa dan negara (Undang Undang Sistem Pendidikan Nasional, Pasal 1 ayat 1 ).

Rumusan tentang pendidikan secara implisit atau eksplisit menunjukan bahwa pendidikan Islam memiliki posisi pertama dan utama dalam bingkai sistem pendidikan nasional. Target pendidikan pertama kali yang harus dihasilkan adalah kekuatan spiritual keagamaan, selanjutnya diikuti dengan pengendalian diri, berkepribadian serta berakhlakul karimah bagi manusia merupakan misi yang harus dicapai oleh pendidikan Islam.

Islam dan manusia ibarat dua sisi mata uang logam yang tidak mungkin dipisahkan. Disatu sisi agama Islam dan pada sisi lainya adalah manusia. Apa yang diajarkan dalam Islam sematamata adalah usaha untuk menata dan membangun karakter manusia agar memperoleh kebahagiaan kehidupan di dunia dan akherat. Berdasarkan asumsi tersebut, maka tanggung jawab pendidikan Islam yang pertama dan utama adalah melahirkan atau mewujudkan profil manusia yang sempurna (insan kamil) dalam artian memiliki cara fikir, sikap, kepribadian dan ketrampilan dalam menjani realitas kehidupan sosialnya. Hal ini diperkuat oleh misi agama Islam sebagai agama rahmatan lil'alamiin sebagaimana firman Allah "Dan tidaklah Kami mengutus kamu melainkan untuk menjadi rahmat bagi semesta alam" (QS. Al Anbiya : 107).

Misi Islam dan pendidikan Islam sangat mulia yaitu memanusiakan manusia dalam artian menjadikan manusia yang ideal baik aspek kecerdasan intelektual (kognitif), kecerdasan pesikologis (affentif) dan kecerdasan mekanik/otot (psikomotorik). Misi islam dan pendidikan haraus benar benar terwujud atau terimplementasi 


\section{Mukhamad Saekan}

kedalam realitas kehidupan sosial sehingga sistem tatanan kehidupan sosial akan tercipta rasa saling menghargai, menghormati, damai, rukun tanpa ada konflik diantara sesama.

Idealisme visi yang dimiliki Islam dan Pendidikan Islam diakui atau tidak, secara langsung ataupun tidak langsung belum terwujud secara optimal. Realitas sosial seringkali menunjukkan fenomena sikap dan perilaku manusia yang jauh dari harapan. Konflik antara kelompok mudah terjadi, perkelahian antara pelajar masih sering kita dengar dan lihat melalui media massa baik cetak maupun media elektronik, pemerkosaan, pembunuhan, dan belum lagi etika saling menghormati antara siswa dengan Guru, saling menghargai antara orang tua dan guru juga belum terwujud secara optimal. Oknum Guru yang melakukan pelecehan seksual kepada peserta dididknya, peserta didik dan oknum orangtua yang melaporkan urusan pendidikan kepada aparat hukum masih sering terjadi.

Pendidikan Islam sebagai bagian tak terpisahkan dari Sistem Pendidikan Nasional bangsa Indonesia harus mampu memberikan pencerahan dalam mewujudkan karakteristik manusia dalam kehidupan sosial. Pendidikan Islam yang memiliki rumusan dari wahyu (al-Qur'an) dan tuntutan nabi (al-Hadis) memiliki peluang besar untuk mewujudkan profil manusia yang sempurna. Apa yang dirumuskan dalam al-Qur'an dan al-Hadis jika tidak dibarengi dengan kualitas pemahaman dan strategi implementasi juga tidak akan bermakna apa apa. Oleh sebab itu para pengelola pendidikan Islam (tenaga pendidik dan tenaga kependidikan) dalam pendidikan Islam harus memiliki cara pandang atau cara berfikir kontekstual dan memiliki strategi aplikatif dalam pendidikan agar pendidikan Islam benar-benar mampu melahirkan profil lulusan dan masyarakat yang mampu memberi kasih sayang/kedamaian (rahmat) kepada siapa saja yang hidup di dunia(lil'alamiin).

Problem kehidupan bangsa Indonesia adalah problem kemanusiaan yaitu kurangnya rasa saling menghormati, saling menghargai antara satu dengan lainnya sehingga mudah dipicu konflik sosial. Pendidikan Islam yang memiliki peran humanistik 
harus mampu mememberikan solusi atau terapi kemanusiaan agar tercipta rasa aman, nyaman dan saling menghagai satu sama lain. Terapi terhadap problem perlu diawali dari asumsi atau cara pandang yang tepat terhadap eksistensi manusia sehingga muncul metode atau teknik dalam membimbing dan membina manusia sesuai dengan tabiat dan hakikat manusia yang sempurna. Disinilah urgensinya perlu ditemukan ideologi kemanusiaan dalam pendidikan Islam untuk menjamin terwujudkan realitas pendidikan dan masyarakat yang damai, toleran anti kekerasan.

\section{B. Pembahasan}

\section{Pendidikan Islam}

Pendidikan Islam seringkali dikonfrontasikan dengan pendidikan barat. Pendidikan Islam tidak jarang digunakan istilah timur. Istilah barat dan timur lebih mengarah kepada istilah geografis dimana kata barat bukan berarti arah barat tetapi lebih bermakna selain Islam sedang istilah timur lebih mengarah kepada kata Islam.

Rancang bangun atau pengertian serta ruang lingkup Pendidikan Islam diturunkan dari filosofi Iqra' yang diambil dari surah pertama kali turun kepada Nabi Muhamamd saw yaitu surat al-Alaq ayat 1-5 "Bacalah dengan menyebut nama Tuhanmu yang menciptakan, Dia telah menciptakan manusia dari segumpal darah, bacalah dan Tuhanmulah yang maha pemurah, yang mengajarkan manusia dengan perantara kalam, Dia mengajar kepada manusia apa yang tidak diketahui".

Dari kacamata sosiologis, ayat ini memiliki tiga hal, pertama perintah untuk membaca kepada umat Islam;kedua, pentingnya manusia mengetahui, memahami dan menyadari adanya Tuhan Sang pencipta manusia;ketiga, pentingnya kesadaran manusia untuk mengetahui siapa dari mana manusia diciptakan.

Proses turunnya Lima ayat dalam satu waktu ini menandakan bahwa manusia minimal harus memiliki tiga karakteristik yang tersurat dalam lima ayat tersesebut yaitu: 


\section{Mukhamad Saekan}

Pertama, setiap manusia harus memiliki kesanggupan untuk membaca dalam artian berfikir, memahami, menganalisis semua fenomena yang ada di dalam kehidupan sosialnya. Setiap detik, menit, jam, hari, minggu, bulan dan tahun manusia harus selalu menggunakan akal pikirannya untuk berfikir, memahami dan menganalisis fenomena yang ada disekitarnya. Hasil pemahaman dijadikan bahan untuk membimbing, membina dan mengatur orang lain sehingga tercipta suasana dan tatanan yang aman, damai, tentram dan bahagia.

Kedua, setiap manusia harus menyadari siapa yang menciptakan dirinya. Pencipta semua yang ada di dunia termasuk pencipta manusia adalah Allah swt yang memiliki kekuatan dan kekuasaan segala-galanya. Manusia dibanding dengan Allah tidak ada apa-apanya. Segala yang dilakukan oleh manusia dimana saja dan kapan saja selalu dilihat ataupasti diketahui oleh Allah swt.

Ketiga, setiap manusia harus mengetahui asal-usul dari mana mereka diciptakan. Manusia diciptakan dari segumpal darah yaitu sesuatu yang dianggap "menjijikan" bagi sebagian orang. Artinya manusia jika dilihat asal-usulnya adalah dari sesuatu yang tidak ada artinya, oleh sebab itu sangat tidak pantas sebagai manusia itu memiliki sikap yang meremehkan orang lain, menyepelekan orang lain, karena asal-usul manusia dari yang remeh dan sepele. Manusia diciptakan dari darah dan awalnya tidak memiliki kemampuan apaapa untuk mengetahui segala sesuatu. Atas kekuatan Allah manusia memiliki kemampuan untuk mengetahui dan memahami segala yang ada di sekitar dirinya.

Berdasarkan penjelasan di atas, maka dapat dikatakan bahwa pendidikan Islam dapat didefinisikan dengan beberapa alternatif diantaranya inspirasi dari A Qodri Azizy (2003:1-3) bahwa pendidikan Islam adalah proses untuk menemukan kebenaran yang didasarkan kepada $\mathrm{Al}$ qur'an, hadis dan rasio sehingga ada perbedaan yang nyata dengan pendidikan barat yang menekankan aspek rasio.

Selain itu, menurut H.M Arifin (1994: 10) menjelaskan bahwa Pendidikan Islam adalah proses melatih mental, moral dan 
fisik untuk menghasilkan sikap dan perilaku (budaya) tinggi untuk mengemban tugas dan tangung jawab dalam kehidupan sebagai hamba Allah swt.

Menurut penulis, pendidikan Islam dapat didefinisikan dengan dua macam cara. Definisi secara umum, pendidikan Islam adalah proses memberi pemahaman atau memahamkan agama Islam kepada dirinya dan orang lain sehingga tercapai kualitas keperibadian yang sempurna (insan kamil). Secara khusus Pendidikan Islam adalah suatu proses yang dilakukan secara sadar dan terencana untuk mengembangkan seluruh potensi dirinya dengan maksud untuk mengetahui hakekat dirinya dalam hubungan antara manusia (hablun min al nas) dan hubungan antara dirinya dengan Allah swt ( hablu min Allah ).

\section{Perbedaan Pendidikan Islam (PI) dan Pendidikan Agama Islam (PAI)}

Pendidikan Islam proses pendidikan yang bersifat umum dalam artian bisa terjadi dimana saja, kapan saja dan dilaksanakan oleh siapapun juga. Sedangkan Pendidikan Agama Islam (PAI) proses pendidikan yang ada di lingkup sekolah (schooling). PAI lebih menekankan proses pembelajaran yaitu proses membelajarkan materi agama Islam agar tercapai kualitas keimanan dan ketakwaan bagi peserta didik.

PAI memiliki ruanglingkup sangat kompleks yang setidaknya ada 3 aspek yaitu (1) knowing, agar peserta didik mengetahui dan memahami ajaran dan nilai niai agama Islam, (2) Doing yaitu agar peserta didik mampu mempraktikan ajaran dan nilai nilai agama Islam, (3) Being yaitu agar peserta didik mampu mengaplikasikan ajaran dan nilai agama Islam kedalam realitas kehidupan sosial (Muhaimin, 2009: 305-306).

Menurut Nusa Putra dan Santi Lisnawati (2013: 1-2) dijelaskan bahwa PAI adalah proses yang sangat kompleks yang memiliki tugas untuk mengasuh, membimbing, mendorong, mengusahakan, menumbuhkembangkan ketaqwaan bagi peserta 


\section{Mukhamad Saekan}

didik. Materi yang disampaikan atau diajarkan kepada peserta didik setidaknya meliputi Aqidah, Akhlaq, al-Qur'an Hadis, Syariah dan Sejarah Islam atau Tarikh.

PAI adalah proses pembelajaran atau interaksi antara Pendidik dan Peserta didik di sekolah atau dilingkungan tertentu yang bertujuan membimbing, membina dan melatih pengetahuan, pemahaman dan keterampilan agar peserta didik mampu menjalani kehidupan sosialnya. Asep Herry Hermawan dkk (2007: 53-54) dalam Buku "Ilmu dan Aplikasi Pendidikan" menjelaskan bahwa ada tiga konsep tentang mengajar yaitu:

Pertama, Teaching as telling or transmission” Mengajar adalah proses menyampaikan atau mentransformasikan sesuatu. Teori ini menitikberatkan kepada aktivitas yang dilakukan guru. Menurut teori ini guru sangat dominan dalam membahas atau menganalisis suatu fenomena sosial.

Kedua, "Teaching as organizing student activity". Teori ini menandaskan bahwa mengajar pada dasarnya adalah mengorganisir kegiatan siswa agar siswa memiliki pengalaman, sikap dan perilaku yang sesuai dengan yang diharapkan. Dalam teori ini bahwa mengajar lebih memberi peran atau posisi siswa dalam mengemukakan, mengapresiasi dan menjelaskan berbagai pengalaman dan fenomena yang dimiliki. Target yang ingin dicapai agar siswa memiliki perasaan sikap yang tepat dalam menempatkan posisi dalam kehidupan sosialnya.

Ketiga, "teaching as making learning possible". Menurut teori ketiga ini, pada dasarnya mengajar adalah perpaduan dari dua aspek yaitu peran guru dan siswa. Artinya peran keduanya bagaikan dua sisi mata auang logam yang tidak mungkin bisa dipisahkan, mengajar perlu mengoptimalkan peran guru dan siswa. Hal ini akan dapat melahirkan perilaku siswa khususnya sikap yang ideal

Ada beberapa metode yang harus dilakukan agar pembelajaran berjalan secara optimal antara lain: 
a. Ceramah yaitu penyampaian materi pembelajaran dengan cara perjelasan atau perkataan agar peserta dididk mengetahui dna memahami materi pelajaran secara optimal. Hal ini sesuai dengan firman Allahswt" Berkata Musa:Ya Tuhankulapangkan untuku dadaku, dan mudahkanlah urusanku, dan lepaskanlah kekauan lidahku, supaya mereka mengerti perkataanlku" (QS Thaaha : 2528-). Artinya sebagaiseorang guru dalam pembelajaran harus disampaikan/dikatakansecara jelas dan logis agar mudah dipahami oleh peserta didik.

b. Diskusiyaitupenyampaianmateripembelajaranyangdilakukan dengan cara bertukar pengalaman dan memmberikan kesempatan peserta didik untuk mengemukakan pendapat terhadap tema yang telah ditentukan. Hal ini sesuai dengan firman Allah swt "Serulah manusia kepada jalan Tuhanmu dengan hikmah dan pelajaran yang baik dan bantahlah mereka dengan cara yang baik. Sesungguhnya Tuhanmu yang lebih mengetahui tentang siapa yang tersesat dari jalan-Nya dan Dialah yang lebih mengetahui orang orang yang dapat petunjuk “(QS An Nahl : 125). Sebagai seorang Guru harus mampu membimbing atau mendampingi proses diskusi peserta didik yang dilakukan dengan cara yang baik dan santun sehingga dengan diskusi materi pelajaran dapat mudah dipahami.

c. Tanya Jawab yaitu proses penyampaian materi pembelajaran yang dilakukandengan dialog secara langsung antara guru dengan siswa. Sesuai dengan firman Allah swt "maka tatkala anak itu sampai pada umur sanggup berusaha bersama sama Ibrahim,Ibrahimberkata:"haianakkusesungguhnyaakumelihat dalam mimpibahwa aku menyembelihmu. Maka fikirkanlah apa pendapatmu", ia menjawab: hai bapakku, kerjakanlah apa yang diperintahkan kepadamu, insya Allah kamu akan mendapatiku termasuk orang orang sabar" (QS. Ash Shaaffat: 102). Sebagai seorang guru harus memberikan kesempatan dengan memberi waktu berfikir dan merenungkan pendapatnya agar peserta didik cepat mengetahui dan memahami materi yang disampaikan oleh guru.

d. Perumpamaan atau bermain peran yaitu cara penyampaian 


\section{Mukhamad Saekan}

materi yang dilakukan dengan cara menampilkan perumpamaan kisah, watak atau karaktertertentu. Sesuai dengan firman Allah swt "Perempumaan mereka adalah seperti orang yang menyalakan api, maka setelah api itu menerangi sekelilingnya Alah hilangkan cahaya yang menyinari mereka dan membiarkan mereka dalam kegelapan, tidak dapat melihat" (QS Al baqarah: 17). Konsekuensinya guru harus memiliki kemampuan memberikan inspirasi agar peserta didik memiliki kemampuan untuk menampilkan peran atau perumpamaan kisah atau karakter tokoh tertentu.

\section{Karakteristik Materi Pendidikan Agama Islam}

Karakteristik adalah ciri khusus dan tanda tanda khusus yang tidak dimiliki pihak lain. Karakteristik Pendidikan Islam adalah ciri khusus yang tidak dimiliki pendidikan selain pendidikan Islam. Karakteristik juga bisa diartikan sebagai keunikan atau keunggulan karena karakteristik ini tidak ada disetiap jenis pendidikan. Karakteristik pendidikan Agama Islam secara khusus dimaksudkan seperangkat pengetahuan dan ketrampilan (kompetensi) yang harus dimiliki setiap peserta didik yang melakukan proses pembelajaran dalam bidang mata pelajaran Pendidikan Agama Islam.

Setiap peserta didik yang belajar PAI harus memiliki pengetahuan, pemahaman dan sekaligus keterampilan dalam menjalankan nilai nilai/pesan agama Islam dalam kehidupan masyarakat. Hal ini didasarkan asumsi, bahwa agama Islam merupakan semangat hidup (spirit of live) bagi para pemeluknya. Agama tidak hanya dijadikan simbol-simbol (hiasan) kehidupan, melainkan benar benar menjadi pedoman, pegangan atau ideologi dalam menjalani kehidupan setiap pemeluknya.

Produk pemahaman terhadap mata pelajaran PAI harus utuh atau komprehensif, artinya pemahaman agama harus dilihat dari berbagai sudut pandang (persepktif). Konsekuensinya setiap pemeluk agama harus memiliki pengatahuan dan pemahaman lintas sektor dalam melihat dan memahami pesan atau pokok bahasan dalam mapel PAI. 
Pokok bahasan sholat tidak sepantasnya hanya dipahami dari aspek formal ritual saja, seperti mengajarkan doa/bacaan, tatacara gerakan dan syarat rukun sahnya pelaksanaan shalat, melainkan harus juga diikuti dengan pemahaman makna setiap gerakan shalat dari sudut pandang ilmu sosilogi, antropologi dll. Memberikan penjelasan atau pemahaman tentang khusyu' dalam sholat tidak bisa dijelaskan hanya dengan materi agama Islam saja, tetapi juga harus dijelaskan dengan pemahaman ilmu psikologi seperti pemahaman tentang konsentrasi. Karena khusyu' dan konsentrasi pada aspek aspek tertentu memiliki kesamaan.

Pokok bahasan zakat fitrah, tidak cukup hanya menyampaikan kepada peserta didik hanya sebatas pengetahuan dan pemahaman tentang tatacara pembagian, doa-doa, ketentuan nisobnya, akan tetapi zakat fitrah juga harus disampaikan pemahaman tentang makna yang ada dalam zakat fitrah yaitu membangun komitmen kepekaan terhadap sesama manusia yang mengalami kesulitan. Oleh sebab itu pokok bahasan zakat fitrah tidak cukup hanya dilihat dari perspektif ilmu fiqh saja melainkan juga dari perspektif ilmu ilmu lain seperti ilmu ekonomi, manajemen, sosiologi dll. Guru PAI harus bisa mengkaitkan antara ajaran zakat, shodaqah dengan pentingnya kesadaran untuk mengentaskan kemiskinan dan membangun komitmen terhadap kaum lemah, anak yatim dan fakir miskin.

Mengajarkan mata pelajaran al-Qur'an Hadis sangat mutlak memerlukan keahlian bagaimana mengkaitkannya dengan ilmu lain seperti ilmu sosiologi dan psikologi. Dalam pemahaman suatu ayat harus juga mengetahui dan memahami sebab-sebab turunnya ayat (asbabun nuzul) yang sangat dekat dengan persoalan sosiologi masyarakat. Pemahaman terhadap asbabun nuzul (aspek sosiologis) minimal akan menghilangkan atau mengurangi cara berfikir tekstualis yang berujung pada sikap anarkhisme atau radikalisme. Munculnya kekerasan dalam beragama disebabkan karena cara berfikir yang tekstualis dan normatif terhadap pesan atau isi yang ada di dalam alQur'an ataupun al-Hadist. 


\section{Mukhamad Saekan}

Berdasarkan asumsi tersebut, dapat dikatakan bahwa karakteristik Pendidikan Agama Islam adalah zig-zag, maksudnyabahwa dalam memahami dan menjelaskan ilmu agama Islam kepada orang lain harus selalu menyangkut atau menyinggung materi lain diluar pendidikan Islam.Konsekuensinya guru PAI harus memiliki pengetahuan, pemahaman dna ketrampilan serba bisa dengan ditandai dengan wawasan luas, mendalam dan komprehensif.

\section{Misi Pendidikan Agama Islam dan Ideologi Kemanusiaan}

Perlunya ideologi kemanusiaan dalam pendidikan dilandasi oleh pemikiran adanya empat pilar pendidikan yaitu learning to know, learning to do, learning to be dan learning tolive together. Learning to know menekankan pentingnya mengembangkan potensi atau ketrampilan intelektual (kognitif). Learning to do menekankan pentingnya peserta didik memahami apa yang diketahui. Pembelajaran tidak hanya mengembangkan kecerdasan atau mengetahui saja, tetapi harus benar-benar memahami apa yang diketahui. Learning to do menekankan pentingnya peserta didik memiliki kemampuan untuk menyesuaikan dengan dinamika yang ada di dalan kehidupan sosialnya. Pendidikan tidak hanya untuk mengembangkan potensi secara intelektual, melainkan harus dapat diapliaksikan kedalam kehidupan sosialnya (lapangan pekerjaan). Learning to live together menekankan pentingnya tercipta manusia yang memiliki kesempurnaan (insan kamil) dalam artian ada kesempurnaan potensi dan keseimbangan antar dimensi inteletual, moral dan ketrampilan, tercipta keseimbangan antara orientasi pribadi dan sosial serta keseimbangan antara kehidupan dunia dan akherat(Budimansyah, 2003: 7-8).

Ideologi dalam PAI terasa aneh dan mungkin bisa dianggap janggal, karena ideologi dalam PAI terdengar asing tidak banyak disebut. Kata ideologi sering muncul dalam bidang ilmu filsafat, dalam beragama, dalam membangun suatu tatanan sistem pemerintahan atau negara dan juga dalam bidang ekonomi dalam 
artian mengembangkan usaha ekonomi. Kata ideoloigi seringkali dikaitkan dengan seorang tokoh besar seperti Plato, Aristoteles, Karl Max, Adam Smith, Max Weber, Emile Dhurkheim. Masing-masing tokoh dipahami memiliki ideologi yang berbeda dan dengan ideologi yang dibangun mereka sukses menjadi tokoh besar dan mampu melakukan perubahan dan sekaligus pembaharuan dalam kehidupan masyarakat. Ideologi ternyata memiliki peranan sangat besar dalam mewujudkan harapan yang telah ditentukan.

Ideologi lahir disebabkab oleh tiga alternatif, pertama, faktor inspiratif. Yaitu ideologi dapat diketahui oleh orang lain didasarkan dari adanya ide dan gagasan seorang tokoh besar. Cara berfikir atau gagasan untuk melakukan perubahan akhirnya memunculkan sebuah ideologi.

Nur Sayyid Santoso Kristeva (2015: 23\&44) Ideologi kapitalis dan liberalis diilhami dari gagasan atau pemikiran tokoh bernama Martin Luther dikenal dengan peletak dasar teosofik yang melakukan protes atau pemberontakan terhadap gereja yang dianggap membatasi atau menghalang halangi kebebasan manusia. Benjamin Franklin dikenal sebagai peletak dasar filosofis bahwa keberhasilan manusia itu ditentukan oleh kemampuan memiliki uang (materi) maka akhirnya muncul semboyan, waktu adalah uang. Adam Smith dikenal sebagai peletak dasar ekonomi dimana gagasannya dituangkan dalam karya berjudul "The Wealth of Nation". Ketiga tokoh tersebut memiliki pemikiran dalam memandang kesuksesan manusia dalam menjalani kehidupan sosialnya. Ideologi sosialis dan komunis diilhami pemikiran dari seorang tokoh bernama St Simon, Fourier, Robert Own, Louis Blane dan Bakunin.

Kedua, faktor keyakinan, yaitu ideologi seseorang itu lahir didorong oleh keinginan atau motivasi yang sangat besar dan kuat. Orang yang memiliki motivasi yang kuat dan besar untuk meraih keberhasilan ekonomi akan melahirkan ideologi ekonomi, orang yang memiliki keinginan besar dan kuat dalam menjalankan agama akhirnya melahirkan ideologi agama. Islam memiliki doktrin dalam sebuah hadis "Inamal 'amaalu binniyat", yang dipahami bahwa 


\section{Mukhamad Saekan}

kesuksesan suatu perbuatan atau tindakan ditentukan oleh motivasi yang tinggi dan kuat.

Berdasarkan asumsi dan teori di atas, dapat dikatakan bahwa Ideologi kemanusiaan adalah suatu cara pandang dan cara berfikir terhadap eksistensi manusia dengan segala variasi atau kebhinekaan yang dimiliki sehingga melahirkan komitmen pelaksana pendidikan (guru) untuk mencapai keberhasilan secara maksimal. Ideologi selalu melekat dalam diri pelaku atau pelaksana pendidikan, artinya selama manusia masih hidup maka selama itu pula akan melahirkan suatu ideologi. Ideologi kemanusiaan menempati posisi sangat penting dalam proses pendidikan karena pendidikan dikatakan sebagai proses memanusiakan manusia (humanisasi) yang memiliki komitmen dan target merubah pengetahuan, sikap dan ketarmpilan manusia menjadi lebih baik.Dari proses tersebut diharapkan manusia memiliki kesuksesan dalam menjalani kehidupan sosialnya. Pendidikan Islam jelas memiliki target untuk melakukan perubahan baik bersifat individual dan sosial untuk mewujudkan tatanan sistem kehidupan yang penuh kebermaknaan. Hal ini didasarkan dengan misi utama agamaIslam diturunkan kedunia sebagai pembawa keberkahan, keselamatan, ketenangan dan kebahagiaan semua makhluk yang ada di dunia.

Pendidikan Agama Islam yang memiliki tujuan utama membimbing, melatih potensi manusia tentunya tidak bisa dilepaskan dari persoalan kemanusiaan. Artinya untuk meraih kesuksesan proses pendidikan Agama Islam maka harus dilakukan dengan menggunakan cara fikir kemanusiaan. Ideologi-ideologi bagaaimana memanusiakan manusia agar manusia menjadi lebih bermartabat dan berbudaya harus terus dikembangkan dan diaplikasikan dalam proses pendidikan dan pembelajaran Islam. Ideologi yang bersifat kemanusiaan secara umum sudah ditekankan dalam Undang-Undang Sistem Pendidikan Nasional, yaitu; a) Pendidikan diselenggarakan secara demokratis dan berkeadilan serta tidak diskriminatif dengan menjunjung tinggi hak asasi manusia, nilai keagamaan, nilai kultural dan kemajemukan bangsa; b) Pendidikan diselenggarakan sebagai 
satu kesatuan yang sistemik dengan sistem terbuka dan multi makna; c) Pendidikan diselenggarakan sebagai suatu proses pembudayaan dan pemberdayaan peserta didik yang berlangsung sepanjang hayat; d) Pendidikan diselenggarakan dengan memberi keteladanan, membangun kemauan dan mengembangkan kreativitas peserta didik dalam proses pembelajaran; e) Pendidikan diselenggarakan dengan mengembangkan budaya membaca, menulis, dan berhitung bagisegenap warga masyarakat; f) Pendidikan diselenggarakan dengan memberdayakan semua komponen masyarakat melalui peran serta dalam penyelenggaraan dan pengendalian mutu layanan pendidikan (bab III, pasal 4 ayat 1-6).

Besarnya unsur kemanusiaan dalam pendidikan berimplikasi kepada perhatian yang besar pula terhadap aspek-aspek kemanusiaan yang ada dalam diri manusia. Artinya Pendidikan Agama Islam akan dapat berhasil jika diperhatikan atau dilihat dari perspektif kemanusiaan. Esensi manusia memiliki berbagai potensi, memiliki berbagai ragam keinginan, memiliki multi persepsi dan rasa yang harus dilihat, dibimbing dan dikembangkan sesuai dengan kodrat atau fitrahnya sebagai manusia. Mendidik manusia tidak bisa disamakan dengan memproduksi bahan bangunan rumah, membimbing manusia tidak bisa dibandingkan dengan memperbaiki kendaraan dalam sebuah bengkel, tidak bisa disamakandengan memperbaiki radio, televisi dan perabot rumah tangga lainnya. Mendidik adalah proses memanusikan manusia, memperlakukan manusia sesuai dengan kodrat yang dimiliki oleh setiap manusia.

Cara pandang terhadap manusia setidaknya bisa didekati dengan tiga cara fikir filsafat yaitu :

Pertama, cara berfikir filsafat idealisme. Cara berfikir atau paham yang menyakini manusia adalah sumber dari semua perubahan dan perbaikan di alam raya ini. Manusia menjadi ujung tombak lahirnya suatu perubahan dan kesuksesan. Jika manusia diberikan kebebasan secara proporsional maka perubahan dan keberhasilan akan cepat tercapai, sebaliknya jika manusiaselalu dibatasi gerak dan cara berfikirrnya maka yang terjadi adalah akan cepat tercapai 


\section{Mukhamad Saekan}

kegagalan atau kerusakan. Keberhasilan hanya ditentukan oleh masing-masing individu atau pribadi yang diberikan kebebasan untuk berfikir dan bergerak. Pembelajaran PAI harus mampu memberikan kebebasan secara proporsional kepada masing-masing peserta dididk agar mudah dan cepat meraih keberhasilan.

Kedua, cara berfikir filsafat materialisme. Cara pandang yang menyakini bahwa keberhasilan manusia ditentukan oleh kemampuan melakukan sikap dan perilaku kolektifitas atau kebersamaan. Kebersamaan diantara sesama manusia menjadi inti dari keberhasilan. Pembelajaran PAI harus memberikan ruang gerak secara optimal untuk menumbuhkembangkan sikap dan perilaku kebersamaan diantara peserta didik. Konsekuensinya Guru dalam pembelajaran PAI harus membimbing dan melatih mengembangkan kemampuan dan keterampilan bekerjasama, berkomunikasi dan berkoordinasi antara peserta didik satu dengan lainnya. Hakekat keberhasilan pembelajaran menurut filsafat ini terletak sejauhmana peserta didik mampu melakukan sinergi atau sikap kolektifitas antara satu dengan lainnya.

Ketiga, cara berfikir filsafat Teologisme yaitu cara pandang yang meyakini bahwa perubahan atau keberhasilan itu ada campur tangan (takdir) dariSang Pencipta alam semesta yaitu Allah swt. Kemampuan dan keterampilan yang dimiliki masing-masing peserta didik tidak akan ada maknanya tanpa kehendak Allah swt. Filsafat ini memberikan kesadaran kepada peserta didik terhadap kualitas keimanan dan ketakwaan yang harus dimiliki setiap manusia yang memeluk agama Islam,konsekeunsinya dalam proses pembelajaran harus memberikan pesan dan mengajarkan pentingnya kesadaran manusia terhadap keberadaan (eksistensi) Sang Pencipta dalam semua aktivitas sehari harinya. Kapanpun dan dimanapun selalu ada Allah swt, apa yang dilakukan setiap manusia tidak bisa lepas dari penglihatan dan sepengetahuan Allah swt. Pembelajaran PAI memiliki tugas utama bagaimana menciptakan kesadaran secara utuh terhadap kualitas keimanan dan ketaqwaan secara utuh dan komprehensif agar tercipta kehidupan yang aman, nyaman, santun 
dan penuh kasih sayang diantara manusia tanpa melihat asal usul agama, suku, warna kulit dan golongannya (Kristeva, 2015:8-10).

Kaitanya dengan hal tersebut muncul sebuah pertanyaan, mengapa dalam pendidikan perlu ideologi kemanusiaan? Jawabanya cukup sederhana, karena pendidikan memiliki tujuan utama melahirkan sikap dan perilaku (tindakan) peserta didik yang ideal dan selalu cocok dengan dinamika perkembangan ilmu pengetahuan, teknologi, dan kebudayaan. Salah satu indikasi keberhasilan pembelajaran dilihat dari sejauhmana peserta didik memiliki perilaku (tindakan) yang sesuaidengan norma sosial dan agama yang berlaku dalam kehidupan sosialnya.

PIP Jones mengutip pendapat Max Weber (2009: 114-115) menjelaskan bahwa tindakan manusia dapat diklasifikan menjadi empat macam yaitu; tindakan tradisional, tindakan efektif, tindakan berorientasi nilai dan tindakan berorientasi rasional instrumen.

Tindakan tradisional didasarkan naluri manusia yang dilakukan dengan melakukan tindakan tanpa diimbangi dengan pertimbangan rasional ataupun nurani. Tindakan afektif didasarkan pertimbangan nilai atau etika antara diperbolehkan atau tidak dieprbolehkan. Dalam hal ini ada pertimbangan norma yang berlaku. Tindakan berorientasi rasional mendasarkan kepada keyakinan atau kebenaran menurut akal pikirannya sendiri. Tindakan berorientasi rasional instumen mendasarkan atas pertimbanagn semua nilai dan norma yang berlaku. Pendidikan Agama Islam harus mampu membimbing dan melatih sehngga mampu mewujudkan sebuah tindakan manusia yang baik dan benar menurut kaidah agama dan sosial.

\section{Implementasi Ideologi Kemanusiaan dalam PAI}

Era dimana kemajuan peradaban sangat maju yang ditandai dengan pesatnya perkembangan teknologi informasi mutlak perlu diimbangi dengan inovasi dalam cara pandang dan metodologi dalam pembelajaran. Ideologi kemanusiaan tidak hanya untuk diingat dan dipahami, tetapi harus diimplementasikan kedalam 


\section{Mukhamad Saekan}

proses pembelajaran PAI agar mampu mewujudkan kualitas proses dan produk pembelajaran pada khususnya dan pendidikan Islam pada umumnya.

Implementasi ideologi kemanusiaan dapat dilakukan dengan implementasi normatif dan implementasi teknis atau praktis. Implementasi normatif ideologi kemanusiaan dalam pendidikan Agama Islam dapat dilakukan dengan beberapa hal sebagai berikut:

Pertama, cara pandang terhadap makna belajar. Belajar pada hekekatnya untuk melakukan perubahan bagi manusia. Islam memandang perubahan disebabkan karena dua hal, pertama perubahan yang bersifat kodrati atau biasa disebut ilmu laduni. Hal ini sesuai dengan firman Allah swt" lalu mereka (musa dan muridnya) bertemu dengan seseorang hamba dari hamba hamba Kami, yang telah kami anugrahkan kepadanya rahmat dari sisi kami dan Kami telah ajarkan kepadanya ilmu dari sisi Kami” (QS. Al kahfi : 65). Ayat ini menjelaskan bahwa keberhasilan bagi manusia itu murni "campur tangan" Allah swt. Kedua, bahwa perubahan yang diperoleh manusia itu murni karena usaha atau ihtiyar yang dilakukan secara optimal. Hal ini sesuai dengan firman Allah swt "bagi manusia ada malaikat malaikat yang selalu mengikutinya bergiliran, dimuka dan dibelakangnya, mereka menjaganya atas perintah Allah swt. Sesungguhnya Allah tidak mengubah keadaan suatu kaum sehingga mereka mengubah keadaan yang ada pada dirinya sendiri. Dan apabila Allah menghendaki keburukan terhadap suatu kaum, maka tak ada yang dapat menolaknya dan sekali kali tak ada pelindung bagi mereka selain Dia" (QS. Al Ra'd: 11).

Kedua,cara pandang terhadap diri sendiri. Keberhasilan dalam belajar diawali dari cara pandnag terhadap dirinya sendiri bagi yang sedang belajar. Semua peserta dididk dalam belajar harus memiliki cara pandang yang tepat terhadap dirinya sendiri. Menurut Imam Ghozali salah satu persyaratan utama yang harus dimiliki oleh pelajar adalah mendahulukan kebersihan jiwa dari akhlak yang tercdela atau rendah (Baharudin dkk, 2007: 44-45). 
Ketiga, Cara pandang terhadap hubungan antara siswa dan Guru. Keberhasilan dalam belajar sangat ditentukan oleh sejauh mana siswa menghormati dan menghargai apa yang diajarkan oleh gurunya. Menurut Al Zarnuji yang dikutip Baharuddin, bahwa siswa tidak akan sukses dalam belajar tanpa mengagumi dan memuliakan terhadp ilmu dan orang yang mengajarnya (guru). Asaumsi inilah yang menjadi dasar utama dalam membangun etika pergaulan dan penghormatan kepada gurunya yang pernah memberikan ilmu pengetahuan kepada peserta didik(Baharudin dkk, 2007: 55).

Keempat, cara pandang terhadap peserta didik/siswa. Belajar yang sukses harus diawali dari kemampuan guru dalam mengetahui dan memahami karakteristik siswa secara utuh dan komprehensif. Karakteristik siswa di definisikan beberapa variabel yang dimiliki dan mempunyai peran dominan mempengaruhi proses pembelajaran yang meliputi latarbelakang pengalaman siswa, kualitas konsentrasi, harapan terhadap hasil belajar tingkat emosional(Asri, 2004: 16).

Peserta didik dalam konteks pembelajaran jangan dianggap benda mati yang bisa dikondisikan atau dirubah sesuai dengan kehendak guru. Siswa dalam proses pembelajaran tidak bisa dipaksa untuk berubah sesuai dengan apa yang disenangi guru. Siswa memiliki potensi dan irama untuk berkembang sesuai dengan karakter atau bakat yang dimiliki. Tugas utama guru dalah mengembangkan dengan membimbing dan melatih bakat yang dimiliki siswa.

Implementasi tehnis atau praktis, ideologi kemanusiaan dalam pembelajaran PAI dapat diwujudkan melalui pendekatan pembelajaran pendekatan siswa aktif (active learning), pendekatan belajar kooperatif (cooperative learning), pendekatan pembelajaran partisipatorik (participatoric learning) dan pembelajaran yang menyenangkan (joyfull learning).

1. Belajar siswa aktif. Cara atau model pembelajaran yang dilakukan dengan menciptakan situasi dan kondisi yang bisa memberikan kesempatan peserta dididk untuk menemukan dan mempraktikan teori. Dasim Budimansyah (2003: 11) mengatakan bahwa pembelajaran aktif bisa dilakukan 


\section{Mukhamad Saekan}

dengan tiga fase yaitu fase perencanaan, pelaksanan dan fase pelaporan. Fase perencanaan, peserta didik diajak untuk brain strorming yaitu mengidentifikasi persoalan yang ada di sekitar dirinya. Peserta didik diajak bersama sama guru untuk menentukan topik atau tujuan yang akan di pelajari sehingga topik tersebut benar-benar dipahami dan dihayati peserta didik. Fase lapangan, peserta didik diajak untuk menuju lapangan untuk mengaktifkan peserta didik dalam mengetahui dan memahami serta mengumpulkan teori yang dilakukan dengan cara wawancara, observasi, menyampaikan angket, dokumentasi. Pada tehnik ini siswa diharapkan memperoleh pengetahuan dan pemahamansecara utuh terhadap topik yang telah ditentukan atau dipelajari. Fase pelaporan, dilakukan dengan portofolio peserta didik, yaitu mengetahui kemampuan peserta didikyang dilakukan melalui kumpulan karya yang dilakukan pada saat fase lapangan. Belajar aktif ini akan mampu menghargai dan mengungkap semua potensi kemanusiaan yang dimiliki peserta didik baik potensi kemanusiaan yang menyangkut kecerdasan kognitif, afektif dan psikomotorik.

2. Belajar kooperatif. Cara atau model pembelajaran yang menekankan atau melatih peserta didik memiliki kemampuan untukmenjalin kerjasama (kooperatif) dengan sesama peserta didikataupun dengan pihaklain. Belajar kooperatif didasarkan oleh asumsi bahwa manusiaa selain sebagai mahluk individual juga sebagai mahluk sosial dan juga makhluk spiritual. Guru sebagai elemen yang bertugas untuk membimbing dan melatih peserta didik harus memiliki kemampuan untuk melatih ketrampilan sosial (kerjasama) peserta didik yang dilakukan dengan tehnik bermain peran, simulasi dan karya wisata. Melalui teknik inilah peserta didik akan terlatih atau terbiasa untuk hidup berdampingan satu dengan lainnya. Islam sangat menjunjung tinggi pentingnya saling bekerjasama, saling mengingatkan dalam hal kebaikan dan kesabaran. Sesuai firman Allah swt "Demi masa, sesungguhnya manusia itu benar benar dalam keadaan rugi, kecuali orang orang yang beriman, 
beramal shaleh dan saling menasehati sepaya mentaati kebenaran dan menasehati supaya menetapi kesabaran" (Al Ashr:1-3). Disinilah urgensi pembelajaran kerjasama yang bertujuan untuk mengembangkan potensi kerjasama atau menasehati satu dengan lainnya.

3. Belajar Partisipatorik. Cara atau model pembelajaran yang menekankan pentingnya keetrlibatan siswa dalam menemukan teori atau kebenaran. Pembelajaran yang mengajarkan pentingnya peserta didik untuk lebih ikut serta atau mengambil peran dalam suatu kegiatan (komunitas). Islam juga menegajarkan pentingnya manusia mengambil peran yang memebrikan kemanfaatan bagi orang lain. Sebuah hadis menjelaskan "Sebaik baik manusia adalah yang mampu memberikan manfaat bagi orang lain" (HR. Ahmad, Thabrani, Daruquttni). Pembelajaran ini dilandasi asumsi learning by doing (belajar sambil melakukan/melakoni). Artinya peserta dididk di ajak untuk melihat dan mempraktikkan secara langsung dari semua tema atau materi yang dipelajri, misalnya materi demokrasi, maka peserta dididk diajaksecaralaangsung melihat proses demokrasis ecara nyata di gedung DPR. Materi toleransi beragama dilakukan dnegan cara mengajak peserta didik kedalam realitas kehidupan atau komunitas multiagama/multi keberagamaan. Melalui partisipasi secara langsung kedalam komunitas nyata, maka peserta didik akan lebih mudah menemukan teori, mengetahui, memahami dan menghayati apa yang dipelajari sehingga mampu diaplikasikan kedalam realitas kehidupan sosial.

4. Belajar menyenangkan. Cara atau model pembelajaran yang dikemas dengan suasana yang menyenangkan sehingga menumbuhkan motivasi tinggi dalam diri peserta didik untuk memahami materi pelajaran. Setiap pembelajaran setidaknya memiliki dua macam yaitu pembelajaran yang efektif dan efisien. Pembelajaran dikatakan efektifjika dapat memberikan atau menambah informasi baru bagi peserta didik. Awalnya tidak mengetahui menjadi mengetahui, awalnya tidak memahami menajdi lebih memahami, awalnya tidak mampu 


\section{Mukhamad Saekan}

mempraktikkan menajdi mampu mempraktikkan suatu teori atau tindakan. Pembelajaran dikatakan efisien jika dilakukan dalam suasana yang menyenangkan dan menggairahkan peserta didik untuk menumbuhkan motivasi belaja. Islam sangat menjunjung tinggi pentingnya suasana yang menyenangkan atau menggembirakan. Sesuai firkan Allah "Dan sampaikanlah kabar gembira kepada mereka yang beriman dan berbuat baik, bahwa bagi mereka disediakan surga surga yang mengalir sungei sungei didalamnya. Setiap mereka diberi rizki buah buahan dalam surga surga itu, menerka mengatakan : inilah yang pernah diberikan kepada kami terdahulu " mereka diberi buah buahan yang serupa dan untuk mereka didalamnya ada isteri isteri yang suci dan mereka kekal di dalamnya" (QS Al-Baqarah: 25). Ayat ini jelas mengajarkan pentingnya umat Islam untuk memebrikan informasi yang menyenngkan atau menggembirakan epada siapapun khususnya kepada orang orang yang bersikap dan berperilaku baik. Pendidikan PAI jelas membimbing dan melatih peserta didik untuk menjadi orang yang baik, oleh sebab itu harus juga dilakukan dengan cara cara yang menyenangkan atau menggemberikan.

\section{Simpulan}

Dari kajian diatas, maka dapat ditarik beberapa simpulan sebagai berikut: pertama,Ideologi kemanusiaan adalah suatu cara pandang dan cara fikir terhadap eksistensi manusia dengan segala variasi atau kebhinekaan yang dimiliki sehingga melahirkan komitmen pelaksana pendidikan (guru) untuk mencapai keberhasilan secara maksima. Hal ini di dasarkan pada asumsi bahwa manusia memiliki berbagai perbedaan atau karakterisrik baik dari aspek fisik maupun psikhis yang harus di pandang dan dipahami secara proporsional oleh para Guru.

Kedua,Ideologi kemanusiaan merupakan suatu keniscayaan yang harus ada dan dimiliki para tenaga pendidik agama Islam (Guru PAI), karena ideologi kemanusiaan dapat menjadi faktor penentu 
keberhasilan kualitas pendidikan agama Islam baik kualitas proses maupun hasil (produk). Pendidikan termasuk pendidikan agama Islam merupakan proses humanisasi yaitu proses membimbing dan melatih agar manusia benar benar berfungsi sebagai manusia. Oleh sebab itu ideologi kemanusiaan menjadi sangat penting dan tidak perlu di tawar tawar lagi.

Ketiga,Ideologi kemanusiaan dalam Pendidikan Agama Islam merupakan suatu doktrin atau komitmen yang sangat penting, karena antara ideologi kemanusiaan dan Pendidikan Agama Islam ibarat dua sisi mata uang logam yang tidak mungkin dipisahkan. Salah satu hilang maka akan mengurangi kualitas proses dan hasil pendidikan Agama Islam. Islam, pendidikan agama islam dan kemanusiaan juga saling terkait dna mengisi, sehingga ketiganya harus dapat dipadukan secara sistemtik agar dapat mencapai kualiats pendidikan sesuai dnegan yang diharapkan.

Keempat,Implementasi Ideologi kemanusiaan dapat dilakukan dengan dua cara, yaitu implementasi normatif dan implementasi tehnis atau praktis. Kedua strategi implementasi harus dipahamidan kuasai oleh Guru PAI agar proses PAI benar benar berjalan sesuai harapan. 


\section{DAFTAR PUSTAKA}

A Qodri Azizy ( 2003), Pengembangan Ilmu Ilmu KeIslaman, Direktur Perguruan Tinggi Agama Islam, Departemen Agama Republik Indonesia, Jakarta.

Arifin (1994), Ilmu Pendidikan Islam: Suatu Tinjauan Teoritisdan Praktis Berdasarkan Pendekatan Interdisipliner. Bumi Aksara, Jakarta Asep Hary hermawan dkk (2007) Ilmu dan Aplikasi Pendidikan, Kumpulan makalah, penyunting Mohamad Ali, R Ibrahim, nana Syaodih Sukmadinata, Djuju Sudjana dan Waini rasyidin, Pedagogiana Press, Bandung Jawa Barat.

Asri Budiningsih (2004), Pembelajaran Moral, Berpijak Pada karakteristik Siswa dan Budayanya, Penerbit, Rineka Cipta, Jakarta.

Baharudin \& Esa Nur Wahyuni (2007), Teori belajar dan Pembelajaran, Ar Ruzz Media, Depok Sleman, Yogyakarta.

Dasim Budimansyah (2003), Model Pembelajaran Portofolio Berbasis Sosiologi, PT Ganesindo, Bandung, Jawa Barat.

Kementerian Agama Republik Indonesia (2012), Al Qur'an dan Terjemahnya, Direktorat jenderal Bimbingan Masyarakat Islam, Direktur Urusan Agama Islam dan Pembinaan Syariah, Jakarta.

Muhaimin (2009), Rekonstruksi Pendidikan Islam, PT. Raja Grafindo Persada, Jakarta.

Kristeva,Nur Sayyid Santoso. (2015), Sejarah Ideologi Dunia: kapitalisme, Sosialisme, Komunisme, Fasisme, Anarkhisme, Anarkhisme- Marxisme, Konservatisme, Lentera Kreasindo, Yogyakarta.

Nusa Putra dan Santi Lisnawati (2013), Penelitian Kualitatif Pendidikan Agama Islam, PT Rosdakarya, Bandung Jawa Barat.

PIP Jones (2009) Pengantar Teori teori Sosial dari Teori Fungsionalisme hingga Post-Modernisme, yayasan Obor Indonesia, Jakarta.

Undang Undang Sistem Pendidikan Nasional Nomor 20 tahun 2003. 